\title{
The Legal Protection of Children Orphaned by HIV/AIDS in Nigeria: An Appraisal
}

\author{
Folake Bejide \\ Faculty of Law, Obafemi Awolowo University, Ile-Ife, Nigeria \\ Email: folakebejide@yahoo.comb
}

Received 25 June 2014; revised 20 July 2014; accepted 13 August 2014

Copyright (C) 2014 by author and Scientific Research Publishing Inc.

This work is licensed under the Creative Commons Attribution International License (CC BY). http://creativecommons.org/licenses/by/4.0/

(c) $\underset{\mathrm{EY}}{\mathrm{B}}$ Open Access

\section{Abstract}

The Human Immunodeficiency Virus and the resultant disease-Acquired Immune Deficiency Syndrome are global epidemics in recent times. Although the effects of the epidemic have been curtailed somewhat in the developed world, it is not so in developing countries. As such it affects not only the infected but those directly dependent on them. Some of the affected people have been identified as children, who turn out to be unprepared for and defenceless against the imminent hardship prevalent as a consequence of the disease. The effects of the epidemic are felt more in the developing world than in developed countries and this is because the attitude of the developed world to the epidemic is positive, enhanced by awareness of the disease; whereas in the developing countries, a lot of myths are attached to it, affecting the requisite attitude needed to combat the epidemic and its effects. This paper seeks to examine the effects of this epidemic on children in Nigeria, comparing the effects on children in other African countries. The paper also looks at structures in place to cater for these children, and then seeks to proffer improved means of protecting their rights.

\section{Keywords}

HIV/AIDS, Orphans and Vulnerable Children, Legal Protection

\section{Introduction}

The Human Immunodeficiency Virus (HIV) and the resultant disease Acquired Immune Deficiency Syndrome (AIDS) are global pandemics in recent years. Since its emergence in 1981, there have been a diversity of measures to curb and curtail its spread but rather than decreasing. The world has experienced increasing numbers of HIV infections. Despite all the measures, there has been no known cure.

According to 2011 estimates from Joint United Nations Programme on HIV/AIDS (UNAIDS), World Health 
Organisation (WHO) and United Nations International Children's Emergency Fund (UNICEF), around 30.6 million adults and 3.4 million children were living with HIV at the end of 2010. Sub-Saharan Africa is by far the region most affected by the epidemic. With just over $12 \%$ of the world's population, it is home to about $68 \%$ of the world's number of people living with HIV [1]. According to UNICEF statistics, the estimated number of People Living with HIV/AIDS (PLWHA) in Nigeria was 3.6 million. Paediatric infections were 360,000. An estimated number of HIV orphans was given as 2.5 million. All estimates were as at 2009 [2].

However, despite efforts at stemming the pandemic, several factors have contributed to the high rates of HIV/ AIDS in Nigeria. These include non-cosmopolitan lifestyle, poverty, inaccessibility to proper health care, lack of adequate awareness as well as a lack of database for monitoring the spread of the disease. In another vein, the multi-ethnicity and multi-cultural nature of Nigeria have hindered the effectiveness of national and international preventive programme [3].

HIV/AIDS was first noticed in the United States of America in 1981. The Center for Disease Control and Prevention in the United States of America (CDC) reported the case of five homosexual men who though previously healthy, were developing pneumocystis carnii pneumonia (PCP) [4]. Their report represented the official announcement of the emergence of HIV/AIDS. By 1982, the CDC adopted the term "Acquired Immune Deficiency Syndrome" (AIDS) to describe the emerging disease [4].

The first two diagnosed cases of HIV/AIDS in Nigeria in 1985 were identified by the Nigerian Institute of Medical Research, (NIMR) Yaba, Lagos. The first case was an adult and the second a 13-year-old girl whom got infected through blood transfusion. The cases were reported in the 2nd HIV/AIDS International Conference in Paris in the following year [5]. The two cases marked the beginning of (documented) cases of HIV/AIDS in Nigeria.

HIV/AIDS is transmissible in three main ways: through unprotected sexual intercourse, through exposure to HIV tainted needles or other body piercing equipment, and through blood transfusion, as well as by mother-tochild transmission during pregnancy or breastfeeding [6]. Elaborating on these vectors, the following categories of people are thus at risk of infection of HIV: people with multiple sex partners especially without the use of condoms; people with substance abuse problems who share needles; use of unsterilized sharp equipment in sub-standard health facilities or beauty care places, babies of mothers who are either unaware of their HIV status or who are not receiving the necessary care for pregnant women who are infected.

\section{Impacts of the HIV/AIDS Crisis}

With over 3 million PLWHA in Nigeria, stigma and discrimination are yet rife against them. Studies have shown that on a daily basis, PLWHA encounter human rights abuses in employment, housing, community, family and health care setting [7]. Despite the preponderance of these discriminatory practices, only few cases have been filed in the courts and decided upon in this regard [8].

HIV/AIDS remains a highly stigmatised disease in Nigeria. Whilst it is agreed that there has been an appreciable improvement in the level of awareness among the people about HIV/AIDS, this has not necessarily translated to behavioural change. Thus in many parts of the country, PLWHA still encounter stigma and discrimination in their daily lives (manifested in the form of denial of access to treatment, denial of employment, denial of housing or denial of right to found a family) [9]. In Nigeria today, because of illiteracy and socio-cultural factors, HIV/AIDS is still seen as a situation that necessitates stigmatisation and even sometimes hatred for those infected and affected by it. Issues like promiscuity, bad luck or misfortune are perceived to be connected with it and thus those affected ought to be ostracised and/or hated. In a situation like this, discrimination sets in which could in turn result in a denial of basic amenities/rights. Also, the loss of one or both parents to AIDS may occasion that the child/children left behind have to fend for themselves for survival. In a situation like this, such children are exposed to child labour, neglect and abuse.

Sadly, even members of the judiciary and legal profession whom ought to be looked up to in ensuring the protection of these rights are also, in some cases, guilty of discriminating against the victims. A notable example is the case of Ahamefule v Imperial Medical Centre \& Anor [10]. Here, a woman living with HIV had her employment terminated because she tested positive to HIV. She sought to challenge the termination of her employment in court. However, in the process, the court requested expert evidence to prove that HIV was not transmissible by casual contact due to her appearance in court. The woman appealed this decision but the Court of Appeal dismissed the appeal on grounds that the order was an interlocutory one and was one of mixed fact 
and law, whereas an appeal that has merit is one only of points of law.

The HIV and AIDS epidemic has undoubtedly impacted every area of the Nigerian society negatively. The most obvious impact is in the area of morbidity and mortality. Next to this, high impact of the disease is also evidenced in the fast rising number of children orphaned by AIDS. Despite the slow progression of HIV to full-blown AIDS, the number of children orphaned by AIDS will continue to rise in years to come (working with available statistics), even if the transmission of the infection is drastically reduced within a short time [11].

\section{Orphans and Vulnerable Children OVC: Children Infected and Affected by HIV/AIDS}

The difficulty in enforcing child's rights begins with the very definition of who a child is in law. There are different definitions depending on the jurisdiction. However, majority of definitions range from 15 years to 18 years as the bench mark of attaining majority.

According to the Child's Rights Act of Nigeria, 2003, a child is any person below the age of 18 years [12]. The definition of an orphan however varies from country to country with variables occurring either in the age or the deceased parent. In Namibia, an orphan is defined as a child under the age of 18 who has lost either of parents (or caregiver) to death, or a child who is in need of care [13]. In Ethiopia, an orphan is a child less than 18 years who has lost both parents regardless of how they died [14].

In 2002, the report Children on the Brink — a joint publication of UNAIDS, UNICEF and USAID—became a standard reference for definitions related to OVC. It defines a child orphaned by HIV/AIDS as a child, under 15 years of age, who has lost at least one parent to AIDS [15].

Vulnerability on the other hand is a little more complex in terms of definition because there is no one universal factor that can be said to make a child vulnerable. Orphanhood itself can be a factor, poverty another, physical disability yet another. Homeless children, children living in armed conflict situations, children in foster care and refugee children have also been described as vulnerable children [15].

"Orphans and Vulnerable Children" (OVC) is a universally used phrase to describe children who have been orphaned from any cause or children who need special care. The term is not limited to orphanhood and vulnerability arising from HIV/AIDS alone but various other causes. There are multiple terms used to describe the orphans and vulnerable children whom are affected by HIV/AIDS, varying from country to country. They include Children Affected by AIDS (CABA), Children and Adolescents Affected by AIDS (CAA), which is reportedly used in Cambodia. Children in Distress (CINDI) which is frequently used in South Africa [15]. In Nigeria, the term People Affected by AIDS (PABA) is used [16].

Worldwide, it is estimated that more than 16 million children under 18 years have been orphaned by AIDS, with 14.8 million of these children in sub-Saharan Africa [17]. Statistics show that the number of orphans due to AIDS alive in 2009 in South Africa was 1,900,000. In Uganda, the number was 1,200,000. And in Zimbabwe, the number was $1,000,000$.

In Nigeria, however, the number was the highest at 2,500,000 [18]. The Federal Ministry of Women Affairs and Social Development, in its Orphan and Vulnerable Children National Plan of Action (2006-2010) corroborate these figures and reported that1.8 million children were orphaned by AIDS in Nigeria in 2003 while the Federal Ministry of Health, in the 2008 HIV sentinel survey report, estimated the figure to be 2.23 million for 2008.

\section{Effects of the HIV/AIDS Pandemic on the OVC}

It is apparent from the above that the HIV/AIDS epidemic has an enormously negative impact on the world. More particularly, it has a profound effect on the children of infected people or the orphans they leave behind.

Emotionally, these children are burdened with the anxiety of the anticipated loss of their loved ones especially when they are turned into the care givers of the sick relatives. In the event of the death of the relative, the anxiety heightens as the child is faced with the stark reality of the loss of their loved ones. The emotional trauma is made worse when the child has to be separated from siblings because of poverty and the need to attach the children left behind to other care givers; needless to say, a caregiver may not be able to take on more than one child [19].

Apart from these, the child also suffers psychologically because of stigmatization. In a society where people are not aware (and sometimes too even when aware), there is that erroneous notion that since a member of a par- 
ticular household is infected, there is the high likelihood that every member of the household is infected. Again the fact that people narrow down the cause of the virus to indecent sexual practices or shared needles by narcotic addicts make the society look down on people infected and affected. This stigmatization often results in discrimination and erodes on some of the rights of the child. For example, such children are made to work harder than others and are sometimes prevented from health services and other amenities and utilities [15].

Orphans and Vulnerable Children as a result of HIV/AIDS, are also negatively impacted in the household. In cases where these children have no one to take them up after the demise of their parents or breadwinner, the household is then transformed to either a female-headed house or a child-headed house, and as a result, more people are dependent on fewer income earners. This in turn exposes children to street begging, stealing, or child labour [16] [19]. These situations further heighten the vulnerability of the affected children.

HIV/AIDS puts OVC at a disadvantage educationally. They may not have the financial resources with which to continue schooling as a result of the ensuing poverty upon the loss of a breadwinner. Apart from these children missing out on formal education, they also miss out on the informal education in the form of valuable life-skills and practical knowledge that parents naturally pass on to their offspring. Lack of both forms of education may make a child low in self esteem and not possess empowerment needed to survive in the society [20]. Education would also, no doubt, equip OVC against greater risk of infection from their infected family members because they will be enlightened as to how to prevent cross-infection.

Apart from the above-mentioned negative impacts on OVC, their health is also greatly compromised. To start with, if these children are not aware of the modes of transmission of the virus, then they stand at a great risk of getting infected themselves. In addition to this, the OVC often end up being malnourished as a result of poverty and inaccessibility to required nourishment. This poverty also tells on their living standards and they end up with other diseases affecting the skin (due to unhygienic environment) and sometimes parasitic infestations in the form of worms [21]. Furthermore, OVC who have been infected by HIV have a problem in complying with the dosage of anti-retroviral drugs. This unfortunately defeats the purpose of preventing full blown AIDS and this situation is referred to as clinical failure [21].

Another problem HIV/AIDS orphans may face may be denial of their inheritance rights. Upon the demise of one or both parents, their offspring ought to ordinarily be entitled to their parent's property (if any and no matter how little). However, the vulnerability of these orphans may cause greedy custodians to mismanage what ought to accrue to them. Families often seek to disinherit AIDS occasioned OVC. Tradition in most ethnic groups in Zambia dictates that the deceased man's family retains all inheritance rights. This practice is commonly referred to as "property grabbing" [22].

\section{Nigerian Government's Response to the Pandemic Especially as Relates to Protecting OVC}

Since the inception of the fourth civilian republic, the national polity has created a conducive environment for national programmes to thrive. In 1999, when President Olusegun Obasanjo assumed office, data from the 1999 seroprevalence survey were presented to him, who in turn immediately formed a Presidential Commission on AIDS (PCA). The PCA comprised of ministers from all sectors, with the president serving as chairperson.

In early 2000, the President formed the National Action Committee on AIDS (NACA), which emphasizes a multisectoral approach to the HIV/AIDS. Membership includes representatives from ministries, the private sector, non-governmental organizations (NGOs) and networks of persons living with HIV/AIDS. State and Local Action Committees on AIDS (SACA and LACA) were also formed to spearhead the local multisectoral response to HIV/AIDS [3].

Narrowing down to OVC, there were research findings that revealed that Nigeria had been providing support to a number of local NGOs to provide care and support to people living and affected by HIV/AIDS. As part of Family Health International comprehensive programming in Nigeria, an OVC assessment was conducted to gather information for the design and implementation of OVC projects in four states (Lagos, Anambra, Osun, Ebonyi) in Nigeria. The findings of the assessment was meant to be used for the design of interventions, which would help address the needs of the children and also provide baseline for monitoring and evaluation of the well being of families over time [23].

In 2009, the Federal Government of Nigeria formulated a National Policy on HIV/AIDS. The overall goal of the National Policy on HIV/AIDS is to provide a framework for advancing the national multi-sectoral response 
to the HIV/AIDS epidemic in Nigeria so as to achieve effective control by reducing the rate of new infections, providing equitable care and support for those infected and affected, and mitigating the impact of the infection, thereby enabling all people in Nigeria to be able to achieve socially and economically productive lives free of the disease and its effects [24]. Particularly for the OVC, Article 2.6.3 of the National Policy commits to providing holistic care and support to various groups of infected people as well as the affected, including children orphaned by AIDS and other vulnerable children. This, the government plans to do by enacting and enforcing legislation to protect the OVC; ensure access to basic necessities without any discrimination; empower caregivers (both on the household and community/group levels) economically; build the capacity of the other tiers of government to offer their own non-discriminatory support; and to ensure availability of support of all forms [25].

On the part of the Education Sector, the highlights of their proposed response to HIV/AIDS in Nigeria are summarised in the UNESCO, Abuja (2003) Publication Education in the Context of HIV/AIDS: A Resource Book. These include the development of a National Strategic Action Plan in line with the country's HIV/AIDS Emergency Action Plan (HEAP); establishment of a critical mass within the Federal Ministry of Education; infusion of Family Life Education and HIV/AIDS issues into curricula of schools and teacher training institutions; use of non-formal strategies (Peer Education, Anti-AIDS Clubs, Drama, Art, Youth Dialogues, Music, Comic Books, Posters, etc.); periodic sensitisation, mobilisation and awareness campaigns; establishment of HIV/AIDS desks at parastatals under the Federal Ministry of Education; useful collaborations with NGOs, Civil Society Organisations, Donor Agencies; establishment of HIV/AIDS Preventive Education Unit at National Teachers Institute, Kaduna [26].

\section{Challenges Faced in Reducing the Problems of OVC}

In spite of all these efforts on the part of the Nigerian government, there are still great challenges in reducing the effects of the epidemic and, in particular, tackling the problems and reducing the number of the OVC. The Nigerian government recognizes the fact that the number of OVC is rising [27] and that given the slow progression of HIV to AIDS, the number of children orphaned by AIDS will continue to rise in the next decade even if the transmission of the infection is drastically reduced within a short time [11].

To start with, there is a huge problem of the lack of a database to give proper estimations with which to work. Similarly, within the education sector, the problems and challenges encumbering the HIV/AIDS interventions and programmes in Nigeria include paucity of data and information and limited research and studies on the prevalence and impact of HIV/AIDS on different aspects of education. Available data to date are predominantly derived by estimation from sentinel sero-prevalence surveys. Other problems within the education sector include a low capacity of educators and education personnel to deal with issues of HIV/AIDS; poor coordination of programmes and intervention responses to HIV/AIDS and education; and poor monitoring and evaluation of programmes and interventions [26].

This however is not to say that the Nigerian government is incapable of solving the problems as this lack of database does not emanate from the government. The attitude of the society to the PLWHA is such that makes them reluctant to show up and register at any Centre designated for them. PLWHA are afraid of the discrimination due to the stigmatization associated with the virus; therefore they prefer to hide their status. Others prefer yet to remain in blissful ignorance as to knowing their status.

Apart from the reluctance, on the part of the infected and affected people to be available for treatment and/or any government response to the pandemic, Nigeria is one of such counties that have alternative health practices which do not involve orthodox medicine practice. Among these are herbal therapies, traditional practices and faith healing, which people sometimes opt for, against orthodox practice. Some of these alternative healthcare are not refined enough as to keep proper records of their clients.

To sum up these challenges, according to an August 2000 Situation Assessment of HIV/AIDS in Nigeria by the Family Health International/Implementing AIDS Prevention and Care Project (FHI/IMPACT), constraints to a national response to HIV/AIDS include:

1) Insufficient funding given the scale and complexity of Nigeria's epidemic;

2) Over-dependence on donor support;

3) Lack of political will and commitment from policy makers;

4) Insufficient number of trained personnel to implement the national AIDS programme; 
5) Need for increased coordination and/or support to local NGOs;

6) Low perception of risk among policymakers and the general population;

7) Weak Sexually Transmitted Infections interventions and surveillance systems;

8) Absence of a reliable national database on HIV/AIDS programs;

9) Lack of supportive legislation for HIV/AIDS programming;

10) Conservative social values, and regional religious and cultural differences; and

11) Poverty and low status of women [3].

\section{The Protection of OVC in Other Jurisdictions}

The number of orphans in some sub-Saharan African countries exceeds one million. Worldwide, it is estimated that more than 16 million children under 18 years have been orphaned by AIDS. Around 14.8 million of these children live in sub-Saharan Africa. In some of the countries within sub-Saharan Africa, children who have been orphaned by AIDS comprise half or more of all orphans nationally [18]. These statistics have made some of the worst hit countries to come up with innovative efforts to provide care and support for these AIDS orphans.

Botswana: In Botswana, traditionally, extended family takes up AIDS orphans. However, due to financial and social constraints, the willingness waned and even where it remained, the orphans were not getting adequate care. It was even discovered that some of the extended families only took on the orphans in order to get the government support and divert such for personal interests [19]. Thus, this led the government to establish the National Orphan Programme in April 1999 to respond to the immediate needs of orphaned children, and a comprehensive policy for helping AIDS orphans was established under this programme [28]. An example of this is the Bobriwa Orphan Trust in the rural district of Bobriwa, contracted to deliver essential services and necessities to the orphans, like home visits, foster placements, food, clothing, and educational needs. By December 2005, over 50,000 orphans were registered to receive support from the government of Botswana. Even though the government had the institutional structures in place to cater for AIDS orphans, they recommended these institutions as a last resort because it was discovered that children would thrive better in their communities than in formal institutions [19].

Malawi: As early as 1991, the government of Malawi established a National Orphan Care Task Force responsible for the general administration of all programmes on orphan care. A year after the establishment of the Task Force, the National Orphan Care Guidelines were established in order to have a broad blueprint to coordinate regional and community efforts. More emphatically, the Task Force also established a sub-committee that is reviewing existing laws and legal procedures to provide greater protection to vulnerable children [28].

Apart from the government, communities in urban and rural Malawi rose to the task of developing ways of coping with the crisis of AIDS orphans; such that many villages had established orphan committees saddled with the responsibility of assessing the local situation and taking collective action to assist those in need. This community-based intervention has the government's full support [29].

In June 2005, the government furthered its commitment to AIDS orphans when President Mutharika launched the National Plan of Action for Orphans and Vulnerable Children. The Action Plan aimed at increasing access to essential services like education, health, nutrition, water and sanitation, as well as assist communities and families in providing support for such children [30].

Zambia: Zambia is one of the worst hit countries by the HIV/AIDS epidemic. According to Stella Goings, a UNICEF representative,

"It's very hard to find a family in Zambia that hasn't been personally touched. It's very hard to find a child that hasn't seen or witnessed a death related to HIV/AIDS. The extended family in the community structure, they've really broken under the weight of the HIV/AIDS epidemic and poverty, and when the burden becomes too great, families are unable to cope anymore, and so we're seeing tremendous numbers of orphans and children who are no longer able to be cared for by their extended family [31].”

In July 2006, the nation's Health Minister stressed the need for increased support for AIDS orphans, through better access to education, health care, nutrition and food, among other things [32]. Thus, the birth of a multisectoral project-Strengthening Community Partnerships for the Empowerment of Orphans and Vulnerable Children (Scope-OVC). This multi-sectoral project is implemented by CARE/Zambia, with help from Family Health International (FHI) and financial support from USAID. This project has been able to offer life-sustaining care and support for the AIDS orphans by working to keep siblings together or at worst within the extended 
family and their communities. Apart from providing support for the communities, scope has also tried to build new as well as sustain old partnerships and networks with other community-based organizations that provide care and support for children [33].

\section{The United States Government's Intervention for OVC in Developing Countries}

As has been discussed above, Orphans and Vulnerable Children face serious risks to their survival and well-being. In response to this global growing crisis, United States President George W. Bush on November 8, 2005, signed into Law the Assistance for Orphans and Other Vulnerable Children in Developing Countries Act (Public Law 109-95), landmark legislation requiring the US Government (USG) to devise a single, comprehensive strategy for addressing critical needs among the developing world's collective of highly vulnerable children [34]. In less than two years of the inception of the Law, amongst other things, the Office of the US Global AIDS Coordinator noted in its March 2007 annual report that 2 million orphans received HIV/AIDS care and support in fiscal year 2006, up from 1.2 million orphans in fiscal year 2005.

Some of the activities conducted by the various USG Agencies, in cooperation with NGOs and international partners, include service delivery, whereby food, prevention education and psychological support was given to children in Kenya; capacity building involving endorsed projects working at eliminating child trafficking and abusive child domestic labour in Ghana [34]. The US President's Emergency Plan for AIDS Relief (PEPFAR) funds the largest service delivery programme for orphans and vulnerable children affected by HIV/AIDS. In the 15 focus countries, FY 2006 funds for care and support of OVC were 152 million dollars. The assistance for these children consisted of a variety of services that included caregiver training; support for access to education; economic support; targeted food and nutritional support; legal aid; medical care; and other social and material support; as well as training for those charged with directly administering the support. For example, the Department of Defense in partnership with the Zambia Defense Force, established a Family Support Unit at a Lusaka military hospital to provide comprehensive family care including voluntary counselling and testing for children and adults; psychotherapy and support groups for adults and children; recreational therapy (e.g., play therapy, kids club, painting, drama); workshops (e.g., prevention, drug/alcohol, nutrition, life skills, income-generating activities); clinical services; tutoring for hospitalized children; outreach activities; and palliative care [34].

Also, the US Department of Agriculture (USDA) food aid agreements with PEPFAR focus countries (FYs 2004-2006) include activities in Kenya, Mozambique, Uganda, and Zambia. USDA's programs have components aimed at AIDS-affected populations in non-focus countries as well: Cambodia, Central African Republic, El Salvador, Guatemala, Indonesia, Malawi, Pakistan, and Senegal. Again, activities include distribution of fortified soymilk to children; development of a fortified food product for AIDS patients; financial assistance to HIV/AIDS affected households; education grants for children from HIV/AIDS-affected families; distribution of maize and pulses to HIV/AIDS-affected households; and distribution of local food to HIV/AIDS-affected households [34].

Another of such activities is the provision of 550,000 scholarships to schoolchildren in sub-Saharan Africa by the Ambassadors' Girls' Scholarship Program. As of June 2006, 180,000 scholarships had been awarded in 40 countries. Recipients are girls from economically poor households and those who are handicapped, orphaned, or adversely affected by HIV/AIDS [34].

\section{Conclusion and Recommendations}

HIV/AIDS no doubt has been a scourge that the world has been battling with in recent decades. While in the developed world, the direct and indirect effects of the epidemic have been contained such that it does not necessarily have to wipe out families. The situation has been made worse in the developing world by the associated problems of poverty, illiteracy and lifestyles.

It is interesting and welcome to see that some of the developed world has seen the scourge, especially as it ravages the developing world, as a challenge that must be overcome. It is even more praise worthy that some of the worst hit countries are not resting on their oars in the drive to curtail this menace. Nigeria, no doubt, is among the countries that have risen up to the challenge of this pandemic.

We have identified various ways how HIV/AIDS affect children, leaving them as orphans and vulnerable children. Much as we note, the efforts Nigerian government has put into trying to contain the epidemic and its direct and indirect effects, and bearing in mind that Nigeria's epidemic is characterized by one of the most rap- 
idly increasing rates of new HIV/AIDS cases in West Africa, it is pertinent to point out that there is still room for improvement in this regard as well as a lot more work that needs to be done.

In view of this, the following are recommended to alleviate the plight of orphans and vulnerable children in Nigeria who have been so made as a result of HIV/AIDS:

1. The government's effort in formulating the National Policy on HIV/AIDS is commendable. More effort is however needed to ensure its implementation if it is to achieve its goal of reducing the rate of new infections, providing equitable care and support for those infected and affected, and mitigating the impact of the infection, thereby enabling all people in Nigeria to be able to achieve socially and economically productive lives free of the disease and its effects.

To start with, the Policy ought to include a worded definition for an orphan or vulnerable child. With the terms clearly defined, the sense of accountability is stronger and the efforts are more specific than those that seem like throwing blind punches. In addition, the Policy ought to be more detailed as to how government plans to go about providing support for these children. Article 2.6.3 of the National Policy commits to providing holistic care and support to various groups of infected people as well as the affected, including children orphaned by AIDS and other vulnerable children. Specific mention ought to be made to show details of how the intended "support" will be provided; whether in the form of providing institutional structures as done in Botswana, or by establishing a National Orphan Task Force as is in Malawi. However, it should be re-emphasised at this point that institutional care for such orphans is not as desirable as having the children grow up in a home setting. Therefore, it should be encouraged that the children be attached to their extended family but with a detailed provision on how any such volunteer extended family would be assisted by the government in catering for these orphans. It is also important to state that there could be this Task Force to ensure compliance such that any government assistance is not diverted to personal use but utilised for the upkeep of the orphans.

2. There ought to be a specific Law in place enacted solely to cater for the needs of orphans and vulnerable children. In the US, the challenge, seen as a huge one, was best approached with the right tool, hence the Assistance for Orphans and Other Vulnerable Children in Developing Countries Act (Public Law 109-95), landmark legislation requiring the US Government (USG) to devise a single, comprehensive strategy for addressing critical needs among the developing world's collective of highly vulnerable children. Nigeria can emulate this approach in order to give the protection of the HIV/AIDS OVC legal backing.

As provided for under Article 5.4.C of the National Policy on HIV/AIDS, the government undertook to enact, disseminate and enforce legislations to protect orphans and vulnerable children against abuse including sexual abuse, violence, exploitation, discrimination, trafficking and loss of inheritance. In Nigeria today, there is no specific law addressing discrimination related to HIV in the country. This is a gap in the Law. It would be recalled that during the UN Declaration of Commitments in 2001, it was agreed that countries of the world should by 2003 enact legislation specifically addressing [emphasis added] HIV-related discrimination in their countries. Sadly, Nigeria is yet to keep up to this promise [9].

No doubt there are existing legislations which indirectly may cover protection of these OVC, nonetheless it would be very advantageous to the situation if a single concise legislation is formulated for this purpose. Some of the existing laws like the Criminal Code, Child Rights Act, the Children \& Young Person's Act and the Constitution do not adequately protect these OVC. For instance, the 1999 Constitution does not contain a specific provision recognising the right to health as an enforceable right in the country. The provision that makes reference to the right to health is Section 17 under Chapter II of the Constitution. This Chapter, captioned "Fundamental Objectives and Directive Principles of State Policy", is non-justiceable by virtue of Section 6(6)(c) of the same Constitution [9].

Another example is found in Section 50 of the Child's Rights Act, 2003. The section provides that certain persons have power to bring children in need to care and protection before a court. Sub-section (1) contains a long list of the different categories of children in need. However, because of the stigmatisation associated with HIV/AIDS, OVCs occasioned by HIV/AIDS may not benefit from this section.

The proposed legislation will specifically cater for the needs of and abuse on these OVCs. The need for a specific law in this regard is justified by the enormity of the negative effects on the OVCs and the fact that existing legislation has not had meaningful impact on their situation.

In addition to the proposed needs, the desired legislation will address (according to the provisions of the Policy), it ought also to contain provisions for an organised structure or institution that will take on the OVC especially those who have no extended family to cater for them, or those whom the extended family may turn into 
slaves because of their unfortunate situation.

3. It is noteworthy that looking through judicially decided cases in Nigeria, one can hardly come across any relating to redressing any form of discrimination suffered by carriers of the virus or persons affected by it, not to mention redress of any discrimination or abuse suffered by the OVC [35]. In other jurisdictions, however, particularly the developing world, some of these cases have been adjudicated upon in the courts [36]. It should be noted at this point however that there may be some perceived reluctance on the part of the victims to seek redress in any open court due to the stigma attached to the disease. As such, the confidentiality and privacy of the affected persons may be sought to be secured by the courts. This issue had been adequately addressed in the English case of X v. Y [37], where the English Court of Appeal considered the public interest exception in relation to the disclosure of information about a person's HIV status and held that public interest in preserving the confidentiality of the hospital records outweigh the public interest in the freedom of the press to publish the information. And thus, the privacy and confidentiality of infected people are secured.

The earlier mentioned Task Force may also take on the responsibility of encouraging people to report any cases of discrimination, abuse, child labour or denial of inheritance (or any other) rights so that the matter may be properly addressed in courts of competent jurisdiction.

4. Governmental financial support ought to be increased and should be felt more by including a vote for these OVC in the budget. It is particularly important because it is not desired that future generations would be wiped away or annihilated by any epidemic. Therefore, everything in the government's arsenal should be used to tackle this unfortunate situation. Statistics may not reveal Nigeria as being affected like other ravaged African countries, but there is evidence to show that Nigeria is having an increased rate of infection [3]. This shows that the issue ought to be priority on government's list, needing urgent attention through financial backing.

5. The government could also infuse the education sector that ensuring that education on prevention of HIV/ AIDS and also on managing those infected and affected could be included in curriculum of schools. Since enlightenment on this disease is still very low in many areas of Nigeria due to illiteracy (deliberate and undeliberate), the education sector could help government in disseminating information and awareness on HIV/AIDS through other teaching aids like dramas, jingles, media houses and campaigns.

6. In addition to what the government is already doing in the Health sector [38], there ought to be a scheme such that there would be a follow up for the orphans who might have been infected by the virus so that health workers can visit the homes/institutions where they are being cared for and ensure strict adherence to the treatment plan offered them at the hospital. This would require a separate set of health workers whose job would be primarily to visit homes to follow up on patients.

7. Finally, the government ought to give a lot of backing to the very many non-governmental organisations that are committed to fighting the HIV/AIDS menace, particularly those aimed at providing succour to the affected children. Government should make the national atmosphere conducive for the work they do.

HIV/AIDS is a global problem and Nigeria is not alone in the effects it is having on the country as well as the struggle to eradicate it. It behoves on every Nigerian to contribute their own quota in stemming the spread and its effects. These anticipated responses of the government can only be effective with the cooperation of the entire populace. Other organs and institutions could also help: religious houses and the family unit would have strong impact in this regard.

\section{References}

[1] (2013) Worldwide HIV \& AIDS Statistics Commentary. http://www.avert.org/worlstatinfo.htm

[2] (2013) UNICEF Statistics. http://www.unicef.org/infobycountry/nigeria_statistics.html\#89

[3] (2012) USAID Brief on HIV/AIDS in Nigeria. www.aegis.com/files/synergyaids/nigeria.pdf.

[4] Gostin, L.O. (2004) The AIDS Pandemic. The University of North Carolina Press, Chapel Hill.

[5] Adeyi, et al. (2013) AIDS in Nigeria: A Nation on the Threshold. In: Chapter 2: The Epidemiology of HIV/AIDS in Nigeria, Harvard Center for Population and Development Studies.

http://nationalmirroronline.net/index.php/health/health-news/15609.html 
[6] Ward, D.E. (1998) The AmFAR AIDS Handbook-The Complete Guide to Understanding HIV and AIDS. W. W. Norton \& Company, New York, 174.

[7] Center for the Right to Health (CRH) (2001) HIV/AIDS and Human Rights: Experiences of People Living with HIV/AIDS in Nigeria.

[8] Odafe \& Others v Attorney General of the Federation and Others (2004) AHRLR 205 (Ng HC 2004) Is One of the Few Decided Cases in this Regard.

[9] Durojaiye, E. (2010) Litigating the Right to Health in Nigeria: Challenges and Prospects in International Law and Domestic Human Rights Litigation in Africa. In: Killander, M., Ed., Pretoria University Law Press (PULP), 162.

[10] (2005) 5 NWLR (pt.917) 51.

[11] Article 1.4 Federal Government of Nigeria National Policy on HIV/AIDS.

[12] Section 277 Thereof. (This Definition Is Also Consistent with Definitions Given in Most Other Jurisdictions. In Most International and National Instruments, a Child Is Defined as a Boy or Girl up to the Age of 18 Years.)

[13] Multisectoral OVC Committee, under the Ministry of Women’s Affairs and Child Welfare, Namibia.

[14] Child, Youth and Family Welfare Organisation, Ethiopia.

[15] Smart, R. (2012) Policies for Orphans and Vulnerable Children: A Framework for Moving Ahead, 3. http://www.hivaidsclearinghouse.unesco.org

[16] Article 5.1 of the National Policy on HIV/AIDS by the Federal Government of Nigeria.

[17] UNAIDS (2012) UNAIDS Report on the Global AIDS Epidemic. http://www.avert.org/aids-orphans.htm

[18] UNICEF/UNAIDS (2012) Children and AIDS: Fifth Stocktaking Report.

http://www.avert.org/aids-orphans.htm

[19] (2012) AVERT: International HIV \& AIDS Charity. http://www.avert.org/aids-orphans.htm

[20] Salaam, T. (2012) Congressional Research Service Orphans and Vulnerable Children (OVC): Problems, Responses and Issues for Congress. http://www.avert.org/aids-orphans.htm

[21] Anyabolu, H. (2012) Consultant Paediatrician and Lecturer, Department of Paediatrics, Obafemi Awolowo University, Ile-Ife, Nigeria. Oral Interview on the health effects of HIV/AIDS on Orphans and Vulnerable Children.

[22] (2012) HIV and AIDS Reference Materials for the Judiciary in Zambia. 21-22. pdf.usaid.gov/pdf_docs/ONADY 162.pdf

[23] Nnamdi-Okagbue, R., et al. (2003) Orphans and Vulnerable Children Assessment in Four States of Nigeria: The Process in Nigeria's Contributions to Regional and Global Meetings on HIV/AIDS/STIs 1986-2003. NIMR, Lagos.

[24] Article 2.4, National Policy on HIV/AIDS.

[25] Article 5.4 C, National Policy on HIV/AIDS.

[26] Ohiri-Aniche, C. and Odukoya, D. (2012) HIV/AIDS and the Education Sector in Nigeria: Review of Policy and Research Documents. ERNWACA-Nigeria. With the Support of IIEP, 14. http://www.rocare.org/HIV AIDS educationsector Nigeria.pdf

[27] Article 1.3, National Policy on HIV/AIDS.

[28] International HIV/AIDS Alliance (2012) Expanding Community-Based Support for Orphans and Vulnerable Children. http://www.avert.org/aids-orphans.htm

[29] Phiri, S. and Webb, D. (2012) The Impact of HIV/AIDS on Orphans and Programme and Policy-Responses. In: Cornia, G., Ed., AIDS, Public Policy and Well Being. http://www.avert.org/aids-orphans.htm

[30] IRIN News (2012) Malawi: New Child Welfare Plan Give Stakeholders Common Platform. http://www.avert.org/aids-orphans.htm

[31] Pbs.org (2012) Orphaned by AIDS. http://www.avert.org/aids-orphans.htm

[32] Medical News Today (2012) Zambia Needs to Implement Policies Addressing AIDS Orphans, Health Official Says. http://www.avert.org/aids-orphans.htm

[33] USAID (2012) USAID Project Profiles: Children Affected by HIV/AIDS. http://www.avert.org/aids-orphans.htm

[34] Yamashita, S.K. (2007) Special Advisor for Assistance to OVC. The US Government Special Advisor for Orphans and Vulnerable Children First Annual Report to Congress, August 2007. http://pdf.usaid.gov/pdf docs/pdack053.pdf

[35] The Notable One of Ahamefule v Imperial Medical Center, Supra Was Not Decided in Favour of the Person Discriminated against. Cf with Decision in South African Case of Minister of Health \& Others $v$ Treatment Action Campaign 
Where the Constitutional Court of South Africa Rejected the Argument of the South African Government That Providing Medication to Prevent Transmission of HIV from Pregnant Women to Their Unborn Babies Was Too Expensive. The Court Based Their Decision on the Point That the Government Contravened the Right to Health as Provided for under Section 27 of the Constitution of South Africa.

[36] Zambia Privatisation Agency v. Matale, ZR 157 (SC) (1995-97) Lemo v. Northern Air Maintenance (pty) Ltd., Industrial Relations Court of Botswana, (2004). J.A.O. v. Homepark Caterers Ltd., Kenya (2004).

[37] 2 All ER 648 (1988).

[38] Providing Free Status Checks and Better Access to Treatment and Management of the Virus. 
Scientific Research Publishing (SCIRP) is one of the largest Open Access journal publishers. It is currently publishing more than 200 open access, online, peer-reviewed journals covering a wide range of academic disciplines. SCIRP serves the worldwide academic communities and contributes to the progress and application of science with its publication.

Other selected journals from SCIRP are listed as below. Submit your manuscript to us via either submit@scirp.org or Online Submission Portal.
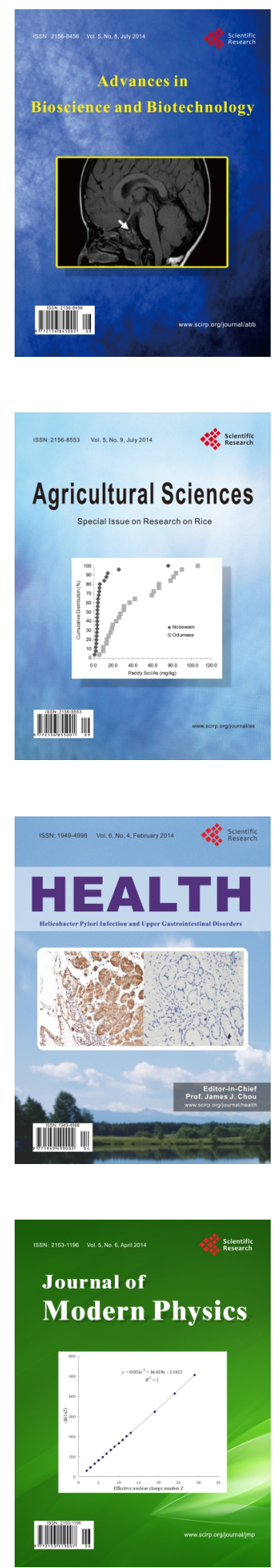
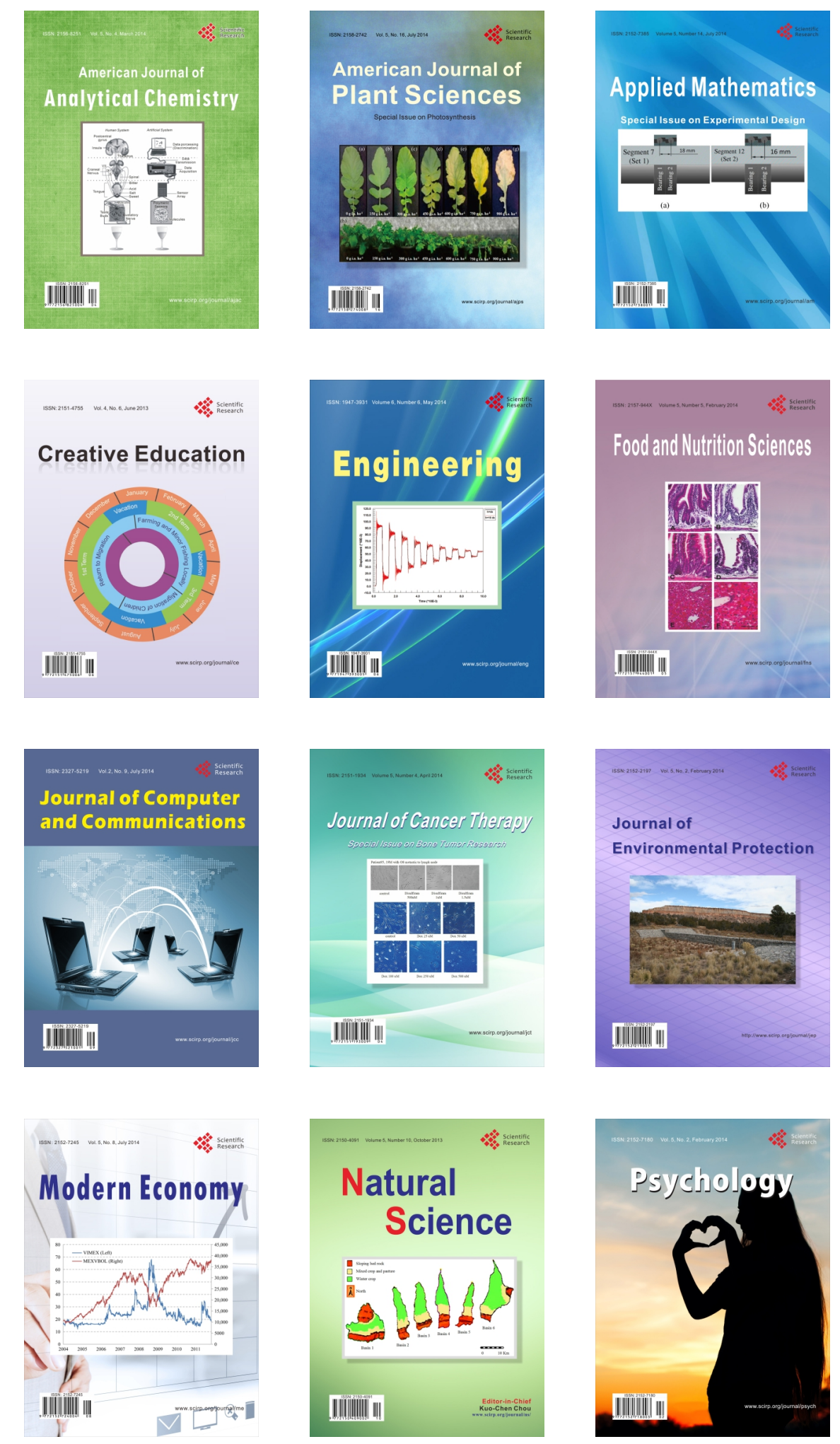